\title{
Tri5 gene expression analysis during postharvest storage of wheat grain from field plots treated with a triazole and a strobilurin fungicide
}

\section{CARLOS BOLANOS-CARRIEL ${ }^{1}$, STEPHEN N. WEGULO ${ }^{1}$, P. STEPHEN BAENZIGER $^{2}$, KENT M. ESKRIDGE $^{3}$, DEANNA FUNNELL-HARRIS ${ }^{4}$, NIKI MCMASTER ${ }^{5}$, DAVID G. SCHMALE III ${ }^{5}$ AND HEATHER E. HALLEN-ADAMS ${ }^{6}$}

\author{
${ }^{1}$ Department of Plant Pathology, University of Nebraska-Lincoln, Lincoln, NE, USA \\ ${ }^{2}$ Department of Agronomy and Horticulture, University of Nebraska-Lincoln, Lincoln, NE, USA \\ ${ }^{3}$ Department of Statistics, University of Nebraska-Lincoln, Lincoln, NE, USA \\ ${ }^{4}$ United States Department of Agriculture USDA-ARS, Wheat, Sorghum, and Forage Research Unit, Lincoln, NE, USA \\ ${ }^{5}$ School of Plant and Environmental Sciences, Virginia Tech, Blacksburg, VA, USA \\ ${ }^{6}$ Department of Food Science and Technology, University of Nebraska-Lincoln, Lincoln, NE, USA
}

(Accepted 28 November 2019)

\begin{abstract}
Fusarium head blight (FHB) and the associated mycotoxin deoxynivalenol (DON) negatively impact the wheat industry worldwide. In North America, FHB is mainly caused by Fusarium graminearum sensu stricto. The purpose of this study was to evaluate, under storage conditions, the expression of the DON biosynthetic gene trichodiene synthase (Tri5) of F. graminearum in grain of hard red winter wheat cultivars 'Overley' (FHB-susceptible) and 'Overland' (moderately resistant to FHB) from field plots treated or untreated with the triazole fungicide Prosaro and the strobilurin fungicide Headline. Infected grain was stored and periodically sampled to determine gene expression by qRT-PCR analysis. The F. graminearum housekeeping gene GAPDH was consistently detected, indicative of metabolically active fungi, and Tri5 detection was significantly higher in 'Overley' compared with 'Overland'. Tri5 gene expression and DON concentrations showed little to no correlation; consequently, Tri5 expression levels did not accurately predict DON concentrations. The strobilurin did not significantly reduce Tri5 gene expression compared with untreated wheat. In the triazole treatment, a significant reduction in the relative expression of Tri5 was detected after 120 days, as well as a downregulation of Tri5 from 60 to 120 days of storage in 'Overley'. In grain from strobilurin-treated plots of both cultivars, the expression of Tri5 increased from 0 to 30 days after tempering. Genetic expression of Tri5 that is necessary for the production of DON can increase during storage of high-moisture grain. Fusarium fungi can persist in wheat kernels for several months postharvest and may actively produce toxin during this period.
\end{abstract}

Keywords: deoxynivalenol, Fusarium head blight, gene expression, strobilurin, triazole, trichodiene synthase, wheat

Résumé: La brûlure de l'épi causée par le fusarium (BEF) et la mycotoxine qui lui est associée, le désoxynivalénol (DON), nuisent à la production de blé à l'échelle de la planète. En Amérique du Nord, la BEF est principalement causée par Fusarium graminearum, stricto sensu. Le but de cette étude était d'évaluer, dans des conditions d'entreposage, l'expression du gène biosynthétique du DON, la trichodiène synthase (Tri5) de F. graminearum, dans les grains de blé de force rouge d'hiver des cultivars 'Overley' (réceptif à l'égard de la BEF) et 'Overland' (moyennement résistant à la BEF) provenant de parcelles traitées avec les fongicides triazole Prosaro et strobilurine Headline, ainsi que de parcelles non traitées. Les grains infectés ont été entreposés et périodiquement échantillonnés pour déterminer l'expression génétique par PCRq en temps réel. GAPDH, le gène constitutif de F. graminearum, a été systématiquement détecté, ce qui est révélateur de champignons métaboliquement actifs, et la détection de Tri5 était significativement plus systématique chez 'Overley' que chez 'Overland'.

Correspondence to: Heather E. Hallen-Adams. E-mail: hhallen-adams2@unl.edu

*Present address: Department of Plant Pathology, 1680 Madison Avenue, Selby Hall, The Ohio State University, Wooster, OH 44691, USA

(C) 2020 The Canadian Phytopathological Society 
L'expression génétique de Tri5 et les concentrations de DON ont affiché peu ou pas de corrélation; en conséquence, les degrés d'expression de Tri5 n'ont pu contribuer à prédire avec précision les concentrations de DON. La strobilurine n'a pas significativement réduit l'expression génétique de Tri5 comparativement au blé non traité. Quant au traitement au triazole, il a permis de détecter, au bout de 120 jours, une réduction significative de l'expression relative de Tri5, de même qu'une régulation à la baisse de Tri5 chez 'Overley' pour un entreposage de 60 à 120 jours. Dans les grains des deux cultivars des parcelles traitées avec la strobilurine, l'expression de Tri5 s'est accrue de 0 à 30 jours après frasage. L'expression génétique de Tri5 nécessaire à la production de DON peut s'accroître durant l'entreposage de grains à forte teneur en eau. Fusarium peut subsister dans les grains de blé pendant plusieurs mois après la récolte et peut activement produire la toxine durant cette période.

Mots clés: blé, brûlure de l'épi causée par le fusarium, désoxynivalénol, expression génétique strobilurine, triazole, trichodiène synthase

\section{Introduction}

Fusarium head blight (FHB) is a major threat to wheat (Triticum aestivum) production worldwide. In North America, FHB is mainly caused by Fusarium graminearum. FHB causes economic losses due to reduction in yield and accumulation of mycotoxins such as deoxynivalenol (DON). Mycotoxins are considered a global food security issue especially in low-income countries and places with deficient management of cereal grain during postharvest storage (Haubruge et al. 2003).

DON is one of many trichothecene mycotoxins, a group of related sesquiterpenoid compounds produced by a wide range of Sordariomycetes. DON inhibits protein synthesis allowing movement of the fungus from cell-to-cell or from floret to rachis in wheat spikes, in which it serves as a virulence factor (Jansen et al. 2005; Brown et al. 2012). Conjugation of DON to a less toxic glucoside (deoxynivalenol-3-glucoside; D3G) plays an important role in wheat resistance to FHB. Transgenic wheat expressing a UDP-glucosyltransferase for DON detoxification had significantly lower FHB compared with controls (Li et al. 2015).

The trichodiene synthase gene (Tri5) catalyses the isomerization and cyclization of farnesyl pyrophosphate to trichodiene as the initial step in the DON production pathway (Hohn and Beremand 1989; Desjardins 2006). Expression of the Tri5 gene during wheat infection is related to the inhibition of plant defence responses such as thickening of the cell wall during the colonization process (Jansen et al. 2005; Mudge et al. 2006). In the FHB-susceptible spring wheat cultivar 'Wheaton', strains of $F$. graminearum with a disrupted Tri5 gene showed reduced virulence and slow development of FHB symptoms (Proctor et al. 1995).

Quantitative reverse transcript PCR (qRT-PCR) can measure the abundance of transcripts of the Tri5 gene in planta (Mudge et al. 2006) and thereby provides an indirect estimate of DON production capacity. In a greenhouse experiment, Hallen-Adams et al. (2011) detected significant differences in the pattern of expression of DON biosynthetic genes during infection of wheat spikes of FHB-susceptible and -resistant spring wheat cultivars 'Wheaton' and 'Alsen', respectively. Various studies have reported Tri5 highly upregulated at 7 days after inoculation of wheat spikes (Mudge et al. 2006), 72 hours after inoculation (Hallen-Adams et al. 2011), and between cell division (growth of head) and cell differentiation (formation of grain) stages in susceptible wheat (Chetouhi et al. 2016), while Brown et al. (2012) detected a peak in Tri5 gene expression during initial asymptomatic infection.

In the wheat $-F$. graminearum pathosystem, FHB and DON are commonly managed through the use of moderately resistant cultivars, but also by applying fungicides. However, the selection of the fungicide chemical class and the fungicide application timing are critical for effective management. In the field, strobilurin fungicides can increase DON levels in wheat (Edwards et al. 2001; Simpson et al. 2001; Pirgozliev et al. 2002; Mesterhazy et al. 2003; Ellner 2005; Blandino and Reyneri 2009; Madden et al. 2014). The mechanism underlying this increase is not known. In contrast, triazole fungicides are effective in controlling FHB and DON (Amarasinghe et al. 2013; Edwards et al. 2001; Pirgozliev et al. 2002; Mesterhazy et al. 2003; Wegulo 2012; Wegulo et al. 2015).

Grain mould pathogens can be divided into preharvest or field, and postharvest or storage, according to their prevalence in different phases during development in the grain ecosystem. FHB-associated pathogens are considered as field moulds; however, poor drying and cleaning practices can lead to postharvest FHB-pathogen colonization and mycotoxin accumulation (Aldred and Magan 2004). During storage, one of the critical factors influencing grain quality is moisture 
content. High grain moisture content is conducive to mycotoxin accumulation in grain (Comerio et al. 1999; Hope et al. 2005). The dynamics of DON production and persistence during postharvest storage of F. graminearum-infected wheat after different fieldapplied fungicide treatments is unknown. The use of quantitative PCR techniques in wheat treated with fungicides provides a method to discriminate among fungicide efficacies which may not apparently differ based on visual disease assessments (Doohan et al. 1999).

Pre- and postharvest management strategies can significantly influence FHB pathogen abundance in grain in the field and during storage. The abundance of FHB pathogens in grain has been shown to be correlated with DON (Demeke et al. 2010; Horevaj et al. 2011). The correlation between Tri5 DNA concentration from trichothecene-producing Fusarium species and DON in harvested grain has been studied using competitive PCR to determine the efficacy of fungicides applied at anthesis in winter wheat (Edwards et al. 2001). Tri5 DNA and DON were at high levels and were positively correlated in inoculated field trials. Additionally, the Tri5-PCR assay showed that metconazole and tebuconazole (triazole fungicides) were highly effective in controlling trichothecene-producing Fusarium, and that the highest concentration of Tri5 DNA (pg ng ${ }^{-1}$ of total DNA) was obtained in grain from azoxystrobin (a strobilurin)-treated plots.

Seed grain provides a good reservoir for FHB pathogens. High loads of Fusarium and DON can be readily detected in grain harvested from wheat fields in an FHB epidemic year. Grain inoculated with $F$. culmorum at anthesis showed 16 times higher concentration ( $\mathrm{pg} \mathrm{ng}^{-1}$ of total DNA) of Fusarium DNA than uninoculated seed lots (Glynn et al. 2007). The Tri5 gene has been used in qRT-PCR to evaluate the relative transcript abundance at different points of kernel colonization. The expression of Tri5 never ceased throughout the entire process of kernel colonization (Hallen-Adams et al. 2011). Tri5 gene expression and mycelial in vitro growth rate of $F$. graminearum were independent and the expression of Tri5 remained constant irrespective of the solute stress and incubation temperature (Marin et al. 2010).

This study was conducted to evaluate the expression of the Tri5 gene in stored grain of winter wheat cultivars 'Overley' (FHB-susceptible) and 'Overland' (moderately resistant to FHB) that were treated in the field with the fungicides Headline (pyraclostrobin; a strobilurin) and Prosaro (prothioconazole + tebuconazole; triazoles).

\section{Materials and methods}

\section{Field experiments}

During the growing seasons in 2015 and 2016, field trials were conducted under dryland and irrigated conditions at the Eastern Nebraska Research and Extension Center (ENREC) near Mead, Nebraska $\left(41.2286^{\circ} \mathrm{N}, 96.4892^{\circ}\right.$ W). The irrigation system consisted of a fixed-superficial rectangular framework. Full Circle Impact Sprinklers (Model 30H; Rain Bird, Azusa, CA) were spaced $6.7 \mathrm{~m} \times 4.6 \mathrm{~m}$ apart, had a trajectory angle of 27 degrees and operated in a range of 25-80 psi (1.7-5.5 bar). Irrigation cycles were programmed using an ICCcommercial irrigation controller model 800 PL (Hunter Industries, San Marcos, CA). Run time cycles were 5 minutes on and 15 minutes off from 10 a.m. to 5 p.m. seven days a week, amounting to $\sim 15 \mathrm{~mm}$ water per day. Irrigated plots received more than twice as much moisture as rainfed plots: $570 \mathrm{~mm}$ vs. $270 \mathrm{~mm}$ from 30 May to 22 June 2015 and 502 vs. $223 \mathrm{~mm}$ from 23 May to 16 June 2016 - timeframes considered critical for $F$. graminearum infection.

Hard red winter wheat cultivars 'Overley' (FHBsusceptible) (Fritz et al. 2004; Wegulo et al. 2011) and 'Overland' (moderately resistant to FHB) (Baenziger et al. 2008; Jin et al. 2013) were sown during the previous autumn in plots measuring $1.2 \mathrm{~m} \times 6.1 \mathrm{~m}$ (autumn 2014; 2015 growing season) or $1.2 \mathrm{~m} \times 4.6 \mathrm{~m}$ (autumn $2015 ; 2016$ growing season). During the third week of April ( $\sim 4$ weeks before anthesis) in both years, field plots were inoculated by spreading corn kernels colonized with $F$. graminearum (67 kernels $\mathrm{m}^{-2}$ ) on the soil surface (Wegulo et al. 2011).

During anthesis, three different treatments were applied to randomly selected plots. Field treatments were (1) triazole, (2) strobilurin, or (3) untreated control plots. The triazole fungicide Prosaro (prothioconazole + tebuconazole; Bayer CropScience) and the strobilurin fungicide Headline (pyraclostrobin; BASF) were applied to spikes at the rate of $0.467 \mathrm{~L} \mathrm{ha}^{-1}$ and $0.657 \mathrm{~L} \mathrm{ha}^{-1}$, respectively, using a $\mathrm{CO}_{2}$-powered backpack sprayer $(241 \mathrm{kPa})$ and four tee-jet nozzles spaced $30.5 \mathrm{~cm}$ apart on a boom. A non-ionic surfactant (Induce) was added to each fungicide/water mixture at a rate of $0.125 \% \mathrm{vol} / \mathrm{vol}$. Untreated plots (sprayed with water only) served as controls. Treatments were replicated four times in a randomized complete block design. Twenty-four hours following fungicide treatment, spikes in all plots were spray-inoculated with a spore suspension of F. graminearum $\left(1 \times 10^{5}\right.$ spores $\left.\mathrm{mL}^{-1}\right)$ using a handpumped backpack sprayer (Wegulo et al. 2011). Plots 
were harvested with a small plot combine when grain moisture content dropped below $15 \%$.

\section{Postharvest storage experiments}

Two postharvest storage experiments (each repeated once) were conducted using grain from the two field trials. In experiment 1, grain of cultivar 'Overland' from dryland plots in the 2015 growing season and subjected to each of the three treatments (triazole, strobilurin and untreated) was used. In experiment 2, grain of cultivar 'Overley' from irrigated plots in the 2016 growing season and subjected to each of the three treatments was used. Grain of cv. 'Overland' contained high levels of Fusarium-damaged kernels (FDK) due to a severe FHB epidemic in 2015. This grain was cleaned to remove FDK using a fractionating aspirator as the uncleaned grain had levels of DON above the range of quantitation, and retaining the harvested quantity of FDK under 16-20\% moisture could lead to sufficient Fusarium growth to destroy the remaining seed and prevent data collection. Additionally, growers clean visibly contaminated grain prior to storage, so this removal of FDK was consistent with standard practice. In 2016, low levels of FHB developed resulting in low or negligible levels of FDK. Therefore, grain of $\mathrm{cv}$. 'Overley' from the 2016 growing season was not cleaned to remove FDK. Additional studies (data not shown) demonstrated comparable DON levels in cleaned 'Overland' grain from 2015 dryland plots and in uncleaned 'Overley' grain from 2016 irrigated plots, so these conditions were chosen for the postharvest study.

Postharvest storage experiments began with dried grain. Grain samples were stored at $32^{\circ} \mathrm{C}$ and $65 \%$ relative humidity (RH). Hydration curves for both experiments were generated based on preliminary studies. Moisture was measured at the beginning of the storage experiment (day 0 ) and at every time point thereafter, and the grain was tempered to $16 \%$ or $20 \%$ moisture by adding water calculated from the following equations: for experiment 1 $\mathrm{Y}=2.11+0.12 \mathrm{X}, \mathrm{R}^{2}=0.70$, and for experiment 2 $\mathrm{Y}=6.47 \mathrm{X}-3.85, \mathrm{R}^{2}=0.96$; where $\mathrm{X}$ is the total millilitres of sterile distilled water to be added to the grain, and $\mathrm{Y}$ is the variation between the initial moisture content of the grain and the desired moisture content.

Non-sterile grain $(300 \mathrm{~g})$, free of solid impurities, was placed on a plastic tray $(50 \mathrm{~cm}$ long $\times 30 \mathrm{~cm}$ wide $\times 3 \mathrm{~cm}$ high) and spread evenly over the tray's surface. Grain samples were brought to desired moisture levels, i.e., tempered with sterile distilled water using a hand-held bottle sprayer. After tempering, grain samples were homogenized manually and transferred to a hermetically sealed sterile Microbox ${ }^{\circledR}$ micropropagation container of dimensions $15 \mathrm{~cm} \times 15 \mathrm{~cm} \times 20 \mathrm{~cm}\left(\mathrm{SacO}_{2}\right.$, Veldeken, Belgium) (Supplementary Figure 1, online). Microbox ${ }^{\circledR}$ containers have a filter in the lid for gas exchange which blocks the entrance of external microorganisms. Water activity $\left(\mathrm{a}_{\mathrm{w}}\right)$ was determined using a Pawkit ${ }^{\circledR}$ water activity meter (Decagon Devices, Pullman, WA). Grain moisture content (\%) was determined using a grain moisture seed tester (DICKEY-john Corp., Auburn, IL), model GAC 500-XT. After 14 days of tempering, grain moisture and $\mathrm{a}_{\mathrm{w}}$ were determined. Sterile distilled water was added to attain $16 \%$ or $20 \%$ grain moisture $\left(a_{w} 0.60\right.$ or 0.75 , respectively). Grain samples were monitored for changes in the percentage of moisture content and $\mathrm{a}_{\mathrm{w}}$ at 30-day intervals. Relative humidity and temperature inside the containers were monitored using a WatchDog ${ }^{\circledR}$ data logger model 1400 (Spectrum Technologies, Thayer Court, IL) (Supplementary Figure 1, online). Samples were stored in a seed storage container (Bally Case \& Cooler, Inc., Bally, PA) in the dark at $10^{\circ} \mathrm{C}$ and $40 \% \mathrm{RH}$.

\section{Deoxynivalenol determination}

From each of the micropropagation containers at a specified storage time $(0,30,60,90$ and 120 days), the mass of grain inside the container was mixed through agitation and homogenized, then a random sample of grain was taken and milled using a cyclone sample laboratory mill (UDY Corporation, Fort Collins, CO). DON quantification was performed in an Agilent 6890/5975 system using gas chromatography-mass spectrometry (GC-MS).

\section{RNA extraction and purification, and cDNA synthesis}

Samples of grain from cultivars 'Overland' (experiment 1) and 'Overley' (experiment 2), at $16 \%$ and $20 \%$ moisture, were collected as above, freeze-dried and stored at $-80^{\circ} \mathrm{C}$ until RNA extraction. RNA extraction was performed on a minimum of six biological replicates (two independent samples of grain were taken from three of the field plot replicates) for each treatment using the hot phenolchloroform and lithium chloride precipitation method according to the specifications of Goswami et al. (2006) with modifications. Freeze-dried grain samples were ground in a mortar and mixed with a heated $\left(80^{\circ} \mathrm{C}\right)$ mixture of 1:1 extraction buffer (Tris-LiCl-EDTA-SDS) and phenol. The extract was transferred into $30 \mathrm{~mL}$ tubes, and a half volume of chloroform was added to the mixture. The mixture was centrifuged for 30 minutes at $2500 \times \mathrm{g}$. An aqueous layer formed at the top of the tube was transferred to a new tube and one third volume of $8 \mathrm{M} \mathrm{LiCl}$ was added. 
The tube was incubated on ice for at least 2 hours. Centrifugation was performed for 5 minutes at 12 $000 \times g$ and $4^{\circ} \mathrm{C}$. The pellet formed at the bottom of the tube was washed with $3 \mathrm{~mL}$ of $2 \mathrm{M} \mathrm{LiCl}$ and $3 \mathrm{~mL}$ of $70 \%$ ethanol. The supernatant was removed and resuspended in $2 \mathrm{~mL}$ ultra-pure DEPC-treated water, followed by the addition of $200 \mu \mathrm{L}$ of $3 \mathrm{M} \mathrm{NaOAc}$, and $5.5 \mathrm{~mL}$ of $95 \%$ ethanol. The suspension was kept at $-80^{\circ} \mathrm{C}$ for 15 minutes, and then centrifuged for five minutes at $12000 \times \mathrm{g}$. The pellet at the bottom of the tube was washed with $3 \mathrm{~mL}$ of $70 \%$ ethanol. Centrifugation and washing were repeated twice. The pellet was dissolved in $100 \mu \mathrm{L}$ ultra-pure DEPC-treated water, and transferred to a $1.5 \mathrm{~mL}$ Eppendorf tube. RNA was quantified using an Eppendorf BioPhotometer plus (Eppendorf North America, Hauppauge, NY). For DNase treatment, a mixture of $2 \mu \mathrm{L}(20 \mathrm{U})$ of Thermo Scientific DNase I (Life Technologies, Carlsbad, CA), $4 \mu \mathrm{L}$ of $10 \times$ incubation buffer, and $88 \mu \mathrm{L}$ of nucleic acids was incubated at $37^{\circ} \mathrm{C}$ for 15 minutes, and then incubated further at $75^{\circ} \mathrm{C}$ for 10 minutes after adding 0.2 M EDTA. $>$ The sample was purified with the RNeasy Mini Kit (Qiagen, Valencia, CA) following the manufacturer's instructions. After RNA purification using the Qiagen kit, the concentration and absorbance at 260/280 nm were taken with the BioPhotometer.

Complementary strand DNA (cDNA) was prepared using the Thermo-Fisher Maxima First Strand cDNA Synthesis Kit for qRT-PCR (Life Technologies, Carlsbad, CA). RNA was adjusted to $1 \mu \mathrm{g}$ per $20 \mu \mathrm{L}$ reaction using molecular biology grade water. On ice, $4 \mu \mathrm{L}$ of $5 \times$ reaction mix and $2 \mu \mathrm{L}$ of reverse transcriptase were mixed together with $14 \mu \mathrm{L}$ of the RNA-water suspension for a total of $20 \mu \mathrm{L}$ volume reaction. cDNA synthesis was conducted in a $\mathrm{T}-100^{\mathrm{TM}}$ thermal cycler (BIO-RAD, Hercules, CA) and the amplification protocol consisted of an initial cycle at $25^{\circ} \mathrm{C}$ for 10 minutes, followed by incubation at $50^{\circ} \mathrm{C}$ for 15 minutes, and final cycle at $85^{\circ} \mathrm{C}$ for 5 minutes.

\section{Quantitative reverse transcript PCR}

Quantitative reverse transcript PCR was conducted in an Eppendorf MasterCycler RealPlex (Eppendorf North America, Hauppauge, NY) using SYBR Green I chemistry. Data acquisition and visualization was carried out by the MasterCycler ep RealPlex software. Primer pairs Tri5-F (5'-TCT ATG GCC CAA GGA CCT GTT TGA3') and Tri5-R (5'- TGA CCC AAA CCA TCC AGT TCT CCA -3'), and GAPDH-F (5'- CTA CAT GCT CAA GTA CGA CTC TTC C - 3') and GAPDH - R (5'- GCC GGT CTC GGA CCA CTT G - 3'), amplifying Tri5 and glyceraldehyde 3-phosphate dehydrogenase (GAPDH; housekeeping gene), respectively (Hallen-Adams et al. 2011) were used in a paired qRT-PCR assay. The housekeeping gene was amplified to normalize the expression of the Tri5 gene. Additionally, wheat actin was used as a control for RNA quality (Hallen-Adams et al. 2011; data not shown). qRT-PCR assays were conducted in a 96well PCR plate. A preliminary assay was conducted using cDNA samples from wheat kernels to determine the optimal primer concentration in the qRT-PCR. Final reaction volume contained: $1 \mu \mathrm{L}$ of undiluted cDNA product, $2.5 \mu \mathrm{L}(25 \mathrm{pmol})$ of each Tri5 primer (forward and reverse) or $1.5 \mu \mathrm{L}(15 \mathrm{pmol})$ of each $G A P D H$ primer, $12.5 \mu \mathrm{L}$ of the Thermo Fisher Maxima SYBR Green qPCR Master Mix (Life Technologies, Carlsbad, CA), and water to $25 \mu \mathrm{L}$. Amplification consisted of an initial denaturation step at $95^{\circ} \mathrm{C}$ for 2 minutes, followed by 40 cycles of denaturation at $95^{\circ} \mathrm{C}$ for 15 seconds, annealing at $55^{\circ} \mathrm{C}$ for 15 seconds, and extension at $68^{\circ} \mathrm{C}$ for 20 seconds. Final holding temperature was $4^{\circ} \mathrm{C}$.

Threshold values from each qRT-PCR assay were adjusted manually. Cycle threshold $(\mathrm{Ct})$ values were determined for Tri5 and GAPDH. Individual $\mathrm{Ct}$ values of the target Tri5 gene were compared with that of the housekeeping gene $G A P D H$, and the relative ratio of expression was calculated (cycle threshold $[\mathrm{Ct}]$ ratio). Normalization of the Tri5 gene expression was done based on the $\mathrm{Ct}$ value of the fungal $G A P D H$ from each corresponding assay. Relative gene expression was calculated using the $2^{-\Delta \Delta C t}$ (Schmittgen and Livak 2008), using the expression of the untreated check plots as calibrators (reference samples).

\section{Experimental design and statistical analysis}

In the field, experimental design was a split plot in randomized complete blocks with four replications, with cultivars ('Overland' and 'Overley') as the main plots and fungicide treatments (triazole, strobilurin and untreated) as the subplots. Dryland and irrigated plots were located in different fields and considered as separate experiments. In the postharvest storage experiments, experimental design was a split-split-plot-in-time with three replications and each experiment was repeated once. Whole plots were the field-applied fungicide treatments (triazole, strobilurin or untreated), subplots were the grain moisture treatments (16\% or $20 \%$ moisture), and sub-subplots were the grain sampling time treatments $(0,30,60,90$ and 120 days). Results did not differ significantly in experiment 1 between $16 \%$ and $20 \%$ moisture treatments, so only the $20 \%$ moisture treatment 
was evaluated in experiment 2 . In the Tri5 gene expression experiment, each run had three biological reps from each fungicide treatment by postharvest storage time combination. Treatments were arranged in a completely randomized design with a factorial of five storage sampling times $\times 3$ fungicide treatments. Statistical analysis of the ratio of Tri5 gene expression relative to GAPDH was carried out with SAS software version 9.4 (SAS Inc, Cary, NC) using generalized linear mixed models (PROC GLIMMIX). Experiments were not combined due to the contrasting environmental conditions of the two growing seasons. Analysis of the two replicate runs of each experiment was conducted separately based on the homogeneity of error variances determined by the F-ratio test (Gomez and Gomez 1984). Ratio of expression was analysed as a function of the fungicide treatment, storage time and the interaction fungicide treatment by storage time. The Satterthwaite approximation was used in the model to account for variances not being equal. Random effects were the rep and the fungicide treatment by rep. The least significant difference test (LSD, $\alpha=0.05$ ) was used to compare pairs of LS means. Combined LS means by run and standard errors (SE) were used to generate graphs.

Pearson correlation coefficients between LS means of the ratio GAPDH/Tri5 and DON, and between LS means of $\mathrm{Ct}$ Tri5 and DON were computed using PROC CORR in SAS. The Chi-square $\left(\chi^{2}\right)$ test was used to determine if the threshold at which the Tri5 gene was detected differed by cultivar ('Overley' versus 'Overland'). A logit test on the binary response distribution was conducted using PROC GLIMMIX. The binary variable consisted of the presence or absence of the gene of interest and/or the reference gene. Type III test of fixed effects was used to determine if there was an effect of fungicide treatments, postharvest storage time, or the interaction between fungicide treatment and storage time on the detection of the Tri5 gene.

\section{Results}

In cv. 'Overland' - 2015 (moderately resistant to FHB; experiment 1), FDK levels after cleaning were: $1.5 \pm 0.8 \%$ in grain from non-treated check plots; $0.8 \pm 0.6 \%$ in grain from Prosaro-treated plots, and $1.6 \pm 1.0 \%$ in grain from Headline-treated plots. In cv. 'Overley' - 2016 (susceptible to FHB; experiment 2), low levels of FHB developed resulting in low or negligible levels of FDK.

In experiment 1, Tri5 was detected in $74 \%$ of the total reactions conducted (300/403) (Table 1). In cv. 'Overley' (susceptible to FHB and DON accumulation; experiment 2), Tri5 was detected in $96 \%$ of the reactions (353/376). The Chi-square test showed a significant difference $(\mathrm{P}<0.001)$ in the frequency of reactions in which Tri5 gene expression was detected in cv. 'Overley' versus cv. 'Overland' (Table 1). Descriptive statistics by experiment in each combination of fungicide treatment by postharvest storage time are presented in Table 2. Overall, the coefficients of variation were low in both experiments with $12.8 \%$ and $8.2 \%$ for $\mathrm{Ct}$ Tri5 and $13.8 \%$ and $12.7 \%$ for the ratio of Tri5 expression relative to $G A P D H$ in experiments 1 and 2, respectively. In most cases the standard deviation in the $\mathrm{Ct} G A P D H$ was higher than in the Ct Tri5 (Table 2). The housekeeping gene GAPDH showed high relative expression (Table 2) denoted as lower $\mathrm{Ct}$ values than Tri5 in both experiments (Table 2).

The effect of the interaction of fungicide treatments by storage time was consistently detected as significant on Tri5 gene expression relative to GAPDH (Ratio $\mathrm{Ct}$ GAPDH/Ct Tri5) (Table 3). Overall, there was an increase in relative Tri5 gene expression during storage (Fig. 1). LSD values $(\alpha=0.05)$ over the total reactions at which Tri5 was detected in both experiments $(n=653)$ showed a significant difference in Tri5 expression at 120 days of storage (Ratio Ct GAPDH/Ct Tri5 $=0.79$ ) compared with the expression registered at 0 days $(0.75)$ and 30 days of storage (0.76). The trend over postharvest storage time is summarized in Fig. 1 for both experiments. In cv. 'Overland' grain from triazole-treated plots, the $\mathrm{Ct}$ ratio of GAPDH/Tri5 increased from 60 days to 120 days of postharvest storage (Fig. 1). However, Tri5 expression in these combinations of fungicide and storage time were not significant compared

Table 1. Count frequency of qRT-PCR reactions for the detection of the Tri5 gene in two winter wheat cultivars with different reactions to FHB and DON, 'Overland' (moderately-resistant; experiment 1) and 'Overley' (susceptible; experiment 2) over two runs.

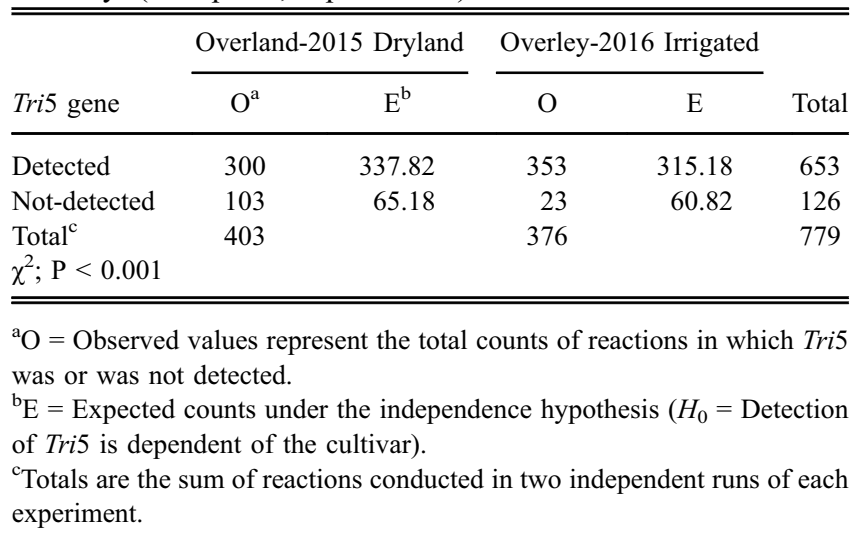


Table 2. Summary statistics on the evaluation of the effect of fungicide treatments applied at anthesis and postharvest storage time on gene detection (Ct GAPDH and Ct Tri5) in grain from the Fusarium head blight (FHB)-moderately resistant cv. 'Overland' and the FHBsusceptible cv. 'Overley' averaged over two runs.

\begin{tabular}{|c|c|c|c|c|c|c|c|c|c|c|c|c|}
\hline \multirow[b]{2}{*}{ Fungicide treatment } & \multirow[b]{2}{*}{ Storage time } & \multirow[b]{2}{*}{ Variable } & \multicolumn{2}{|c|}{ Total reactions } & \multicolumn{2}{|c|}{ Mean } & \multicolumn{2}{|c|}{ Standard Deviation } & \multicolumn{2}{|c|}{ Minimum } & \multicolumn{2}{|c|}{ Maximum } \\
\hline & & & Overland & Overley & Overland & Overley & Overland & Overley & Overland & Overley & Overland & Overley \\
\hline \multirow[t]{10}{*}{ Check } & 0 & $\mathrm{Ct} G A P D H$ & 25 & 21 & 23.37 & 23.82 & 3.66 & 3.56 & 17.71 & 18.65 & 32.71 & 30.71 \\
\hline & 0 & Ct Tri5 & 25 & 20 & 31.33 & 32.28 & 4.15 & 2.23 & 24.49 & 29.14 & 38.19 & 36.34 \\
\hline & 30 & Ct $G A P D H$ & 19 & 22 & 25.76 & 22.00 & 4.63 & 1.56 & 19.03 & 18.57 & 34.91 & 25.53 \\
\hline & 30 & Ct Tri5 & 17 & 21 & 33.11 & 31.08 & 3.73 & 1.91 & 25.64 & 28.19 & 37.34 & 35.33 \\
\hline & 60 & Ct $G A P D H$ & 23 & 20 & 25.64 & 25.34 & 4.03 & 3.43 & 17.58 & 20.53 & 36.12 & 34.61 \\
\hline & 60 & Ct Tri5 & 23 & 20 & 31.85 & 32.90 & 5.77 & 3.09 & 18.90 & 27.99 & 39.07 & 39.71 \\
\hline & 90 & Ct $G A P D H$ & 18 & 21 & 26.79 & 25.00 & 3.84 & 2.99 & 20.62 & 21.70 & 33.97 & 33.26 \\
\hline & 90 & Ct Tri5 & 16 & 21 & 34.44 & 31.95 & 4.12 & 1.55 & 24.83 & 28.54 & 39.71 & 34.92 \\
\hline & 120 & $\mathrm{Ct} G A P D H$ & 25 & 20 & 26.40 & 24.36 & 3.09 & 3.70 & 22.04 & 19.53 & 32.44 & 35.25 \\
\hline & 120 & Ct Tri5 & 25 & 21 & 33.49 & 30.57 & 4.05 & 1.53 & 25.16 & 27.19 & 39.61 & 32.80 \\
\hline \multirow[t]{10}{*}{ Strobilurin } & 0 & $\mathrm{Ct} G A P D H$ & 24 & 29 & 25.29 & 22.44 & 3.41 & 2.60 & 18.32 & 18.22 & 31.40 & 31.11 \\
\hline & 0 & Ct Tri5 & 23 & 29 & 33.26 & 30.34 & 4.52 & 3.07 & 25.94 & 24.95 & 39.04 & 36.14 \\
\hline & 30 & $\mathrm{Ct} G A P D H$ & 31 & 29 & 25.53 & 24.03 & 3.33 & 4.02 & 18.74 & 18.88 & 35.13 & 34.27 \\
\hline & 30 & Ct Tri5 & 30 & 29 & 32.25 & 30.36 & 4.58 & 1.86 & 24.16 & 26.77 & 39.77 & 33.90 \\
\hline & 60 & $\mathrm{Ct} G A P D H$ & 28 & 27 & 26.52 & 23.98 & 3.43 & 2.79 & 22.04 & 18.77 & 34.35 & 29.64 \\
\hline & 60 & Ct Tri5 & 24 & 27 & 34.20 & 31.56 & 2.69 & 2.75 & 28.29 & 26.70 & 39.26 & 36.29 \\
\hline & 90 & $\mathrm{Ct} G A P D H$ & 27 & 28 & 26.04 & 23.93 & 3.46 & 2.96 & 17.30 & 18.82 & 33.92 & 29.76 \\
\hline & 90 & Ct Tri5 & 22 & 26 & 33.29 & 31.61 & 4.47 & 2.51 & 16.99 & 27.23 & 38.09 & 36.60 \\
\hline & 120 & $\mathrm{Ct} G A P D H$ & 26 & 29 & 26.43 & 23.23 & 3.31 & 4.58 & 19.84 & 17.80 & 32.62 & 34.79 \\
\hline & 120 & Ct Tri5 & 22 & 28 & 34.32 & 30.68 & 3.48 & 3.18 & 28.20 & 24.92 & 39.94 & 37.08 \\
\hline \multirow[t]{10}{*}{ Triazole } & 0 & $\mathrm{Ct} G A P D H$ & 22 & 25 & 26.40 & 24.15 & 3.57 & 2.47 & 17.59 & 20.74 & 30.42 & 29.61 \\
\hline & 0 & $\mathrm{Ct}$ Tri5 & 15 & 22 & 32.90 & 31.62 & 5.23 & 3.23 & 19.38 & 27.29 & 38.70 & 37.96 \\
\hline & 30 & $\mathrm{Ct} G A P D H$ & 31 & 25 & 26.33 & 24.71 & 4.60 & 2.28 & 17.17 & 21.34 & 35.10 & 28.54 \\
\hline & 30 & Ct Tri5 & 23 & 23 & 33.46 & 33.10 & 5.38 & 2.25 & 19.19 & 29.49 & 39.76 & 37.59 \\
\hline & 60 & $\mathrm{Ct} G A P D H$ & 21 & 24 & 28.45 & 23.27 & 3.24 & 2.52 & 23.21 & 19.51 & 33.11 & 31.67 \\
\hline & 60 & Ct Tri5 & 16 & 22 & 34.48 & 32.13 & 3.03 & 2.04 & 29.60 & 27.56 & 39.27 & 35.61 \\
\hline & 90 & $\mathrm{Ct} G A P D H$ & 26 & 25 & 26.89 & 24.45 & 3.51 & 3.00 & 20.14 & 19.87 & 35.85 & 31.43 \\
\hline & 90 & Ct Tri5 & 23 & 25 & 31.28 & 32.45 & 3.36 & 2.92 & 25.69 & 27.74 & 38.17 & 38.87 \\
\hline & 120 & $\mathrm{Ct} G A P D H$ & 23 & 25 & 27.47 & 23.43 & 3.31 & 2.88 & 22.85 & 20.19 & 33.51 & 31.60 \\
\hline & 120 & Ct Tri5 & 23 & 25 & 32.11 & 30.93 & 2.91 & 2.56 & 24.71 & 26.99 & 37.65 & 36.50 \\
\hline
\end{tabular}

Table 3. ANOVA summary on the evaluation of fungicide treatments applied at anthesis and storage time on Tri5 gene expression relative to GAPDH (Ratio Ct GAPDH/Ct Tri5) in grain from the FHB-moderately resistant cv. 'Overland' and the FHB-susceptible cv. 'Overley'.

\begin{tabular}{|c|c|c|c|c|c|c|c|c|c|c|c|c|}
\hline \multirow[b]{3}{*}{ Source } & \multicolumn{6}{|c|}{ 2015-Overland Dryland (Experiment 1) } & \multicolumn{6}{|c|}{ 2016-Overley Irrigated (Experiment 2) } \\
\hline & \multicolumn{3}{|c|}{ Run 1} & \multicolumn{3}{|c|}{ Run 2} & \multicolumn{3}{|c|}{ Run 1} & \multicolumn{3}{|c|}{ Run 2} \\
\hline & $\mathrm{Df}^{\mathrm{a}}$ & $\mathrm{F}$ value & P-value & df & F value & P-value & df & F value & P-value & $\mathrm{df}$ & F value & P-value \\
\hline $\begin{array}{l}\text { Fungicide } \\
\quad \text { Treatment }(F)\end{array}$ & 2 & 0.29 & 0.766 & 2 & 0.72 & 0.527 & 2 & 1.09 & 0.395 & 2 & 0.53 & 0.612 \\
\hline Storage Time $(T)$ & 4 & 1.11 & 0.353 & 4 & 2.55 & 0.042 & 4 & 0.12 & 0.974 & 4 & 1.92 & 0.109 \\
\hline$F^{*} T$ & 8 & 1.90 & 0.065 & 8 & 2.45 & 0.016 & 8 & 2.46 & 0.016 & 8 & 2.28 & 0.025 \\
\hline Residual & 130 & & & 140 & & & 167 & & & 156 & & \\
\hline
\end{tabular}

${ }^{a}$ The number of degrees of freedom was dependent of the total reactions in which Tri5 and GAPDH were detected.

with strobilurin-treated grain at 30 days and untreated checks at 60 and 120 days of storage (Fisher-LSD; $\alpha=0.05$ ). Although a significant increase of Tri5 gene expression was detected in cv. Overland grain from strobilurin-treated plots from 60 to 120 days of storage, the detection of the gene of interest was significantly lower $(\mathrm{P}=0.015$; logit test of the binary response distribution) in the grain from triazole-treated (Tri5 detected 


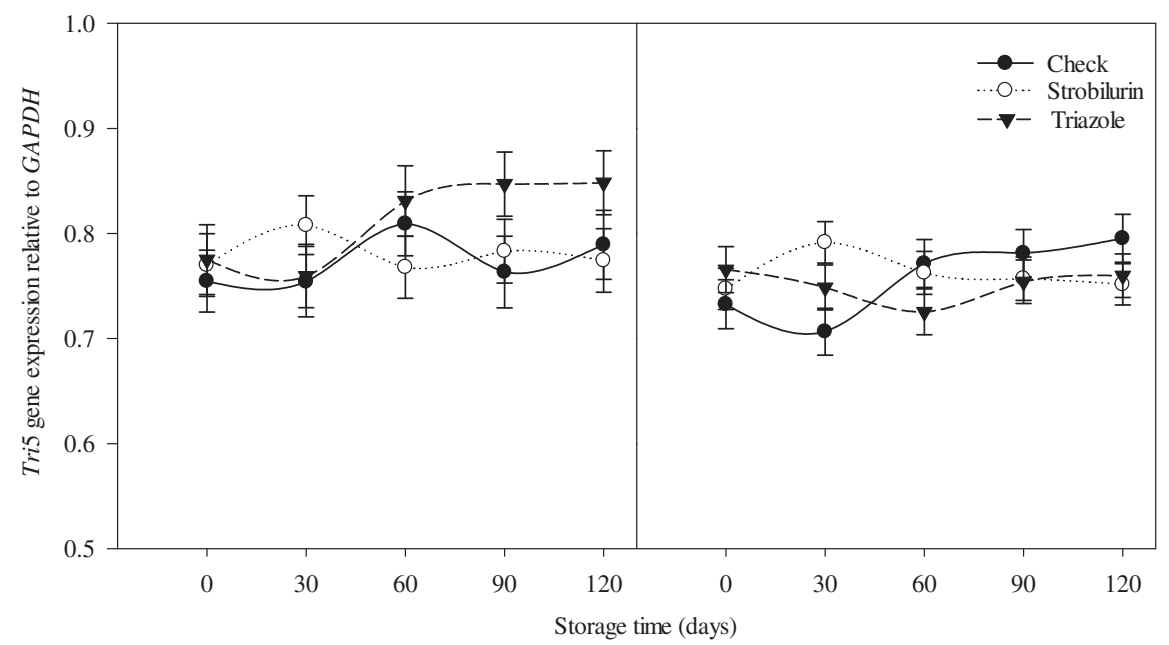

Fig. 1 Effect of postharvest storage time on Tri5-gene expression relative to GAPDH (Ratio Ct GAPDH/Ct Tri5) in grain from triazole (Prosaro)- and strobilurin (Headline)-treated plots at anthesis, and non-fungicide sprayed (Check) plots in the 2015 growing season in cv. 'Overland' (moderately resistant to FHB) (experiment 1; left), and in the 2016 growing season in cv. 'Overley' (susceptible to FHB) (experiment 2; right). LS-means are from two independent runs of each experiment. Error bars indicate SE of the LS-means.

in $66 \%$ of samples in experiment $1 ; 94 / 142$ ) than in the strobilurin-treated (81\% Tri5 detection; 116/144) and untreated check plots (77\% Tri5 detection; 90/117).

In cv. 'Overley', Tri5 gene expression levels were higher in grain from strobilurin-treated plots (ratio $\mathrm{Ct}$ $G A P D H / C t$ Tri5 $=0.79$ ) compared with grain from triazole-treated plots $(0.73)$ and untreated check plots $(0.75)$. The strobilurin did not significantly reduce Tri5 gene expression compared with the untreated grain (Fig. 1).

In 'Overland' (2015 experiment), samples were tempered to $16 \%\left(\mathrm{a}_{\mathrm{w}}=0.60\right)$ and $20 \%\left(\mathrm{a}_{\mathrm{w}}=0.75\right)$ grain moisture content. In this study, DON concentrations as well as Tri5 gene expression were similar at $16 \%$ and $20 \%$ moisture with P-values of 0.878 and 0.435 , respectively; therefore, 2016 experiments were conducted using grain tempered at $20 \%$.

At the first evaluation after tempering the grain (30 days of storage), grain from strobilurin-treated plots showed a consistent increase in Tri5 gene expression compared with that from untreated check plots (Fig. 2). A 2.6-fold and 4.4-fold change in gene expression was detected in cv. 'Overland' (experiment 1) and cv. 'Overley' (experiment 2), respectively. In both experiments, from 30 to 120 days of storage, fold changes in gene expression were variable without a clear trend and dependent on the expression of the untreated reference sample calibrator instead of a clear fungicide effect (Fig. 2). In grain from cv. 'Overland' (experiment 1) treated with triazole, Tri5 was 0.8 times downregulated from 0 to 30 days of storage (Fig. 2).
Fungicide treatments applied at anthesis had a highly significant effect $(\mathrm{P}<0.001)$ on DON concentration in both experiments (Fig. 3). Grain from Headline-treated plots showed the highest concentration of DON which was significantly different than the concentration measured in grain from the non-fungicide treated plots, and in grain from Prosaro-treated plots in both experiments. However, in both experiments, Pearson's correlation coefficients were not significant between DON concentration and either the $\mathrm{Ct}$ ratio GAPDH/Tri5 or DON-Ct Tri5 (Fig. 4).

\section{Discussion}

Under poor storage conditions, the risk of mycotoxin contamination in small grains may increase due to the growth of $F$. graminearum in the grain (Hope et al. 2005; Magan et al. 2014). In this study, qRT-PCR was conducted to track potential changes, under postharvest storage conditions, in gene expression of the Tri5 gene in grain from field plots treated with a triazole (Prosaro) or a strobilurin (Headline) fungicide.

Detection of Tri5 expression during postharvest grain storage was higher in cv. 'Overley' (FHB-susceptible) than in cv. 'Overland' (moderately resistant) regardless of fungicide treatment. Spread of Fusarium through the wheat spike is promoted by DON, and higher Tri5 expression (and thus higher DON) in the susceptible cultivar would lead to higher levels of infection and spread of the fungus within the plant (Bai et al. 2001; Jansen et al. 2005; Jiao 


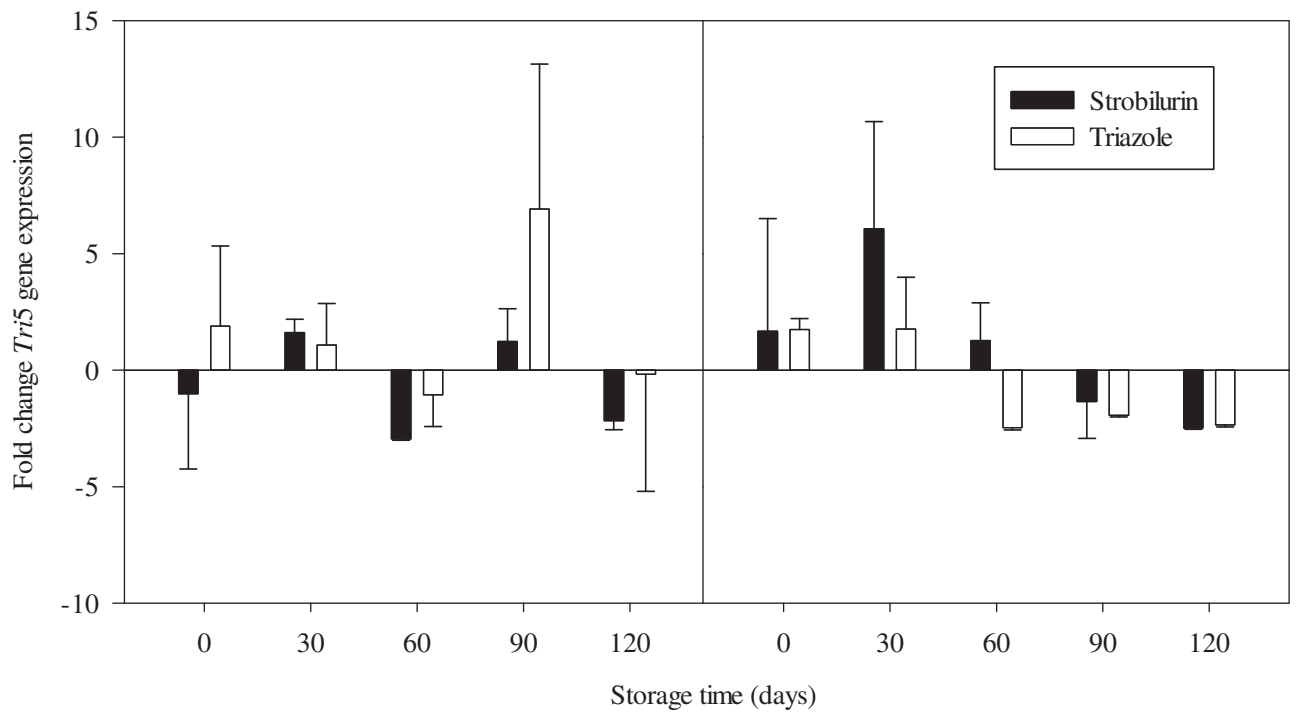

Fig. 2 Fold change in Tri5 gene expression relative to the GAPDH in wheat grain from triazole (Prosaro)- and strobilurin(Headline)-treated plots of cv. 'Overland' (moderately resistant to FHB) (experiment 1; left) and cv. 'Overley' (susceptible to FHB) (experiment 2; right). Nonfungicide treated plots were used as calibrators (reference samples). Data for $2^{-\Delta \Delta \mathrm{Ct}}$ calculation correspond to LS-means averaged over two independent runs of each experiment. Error bars indicate SE of the LS-means.

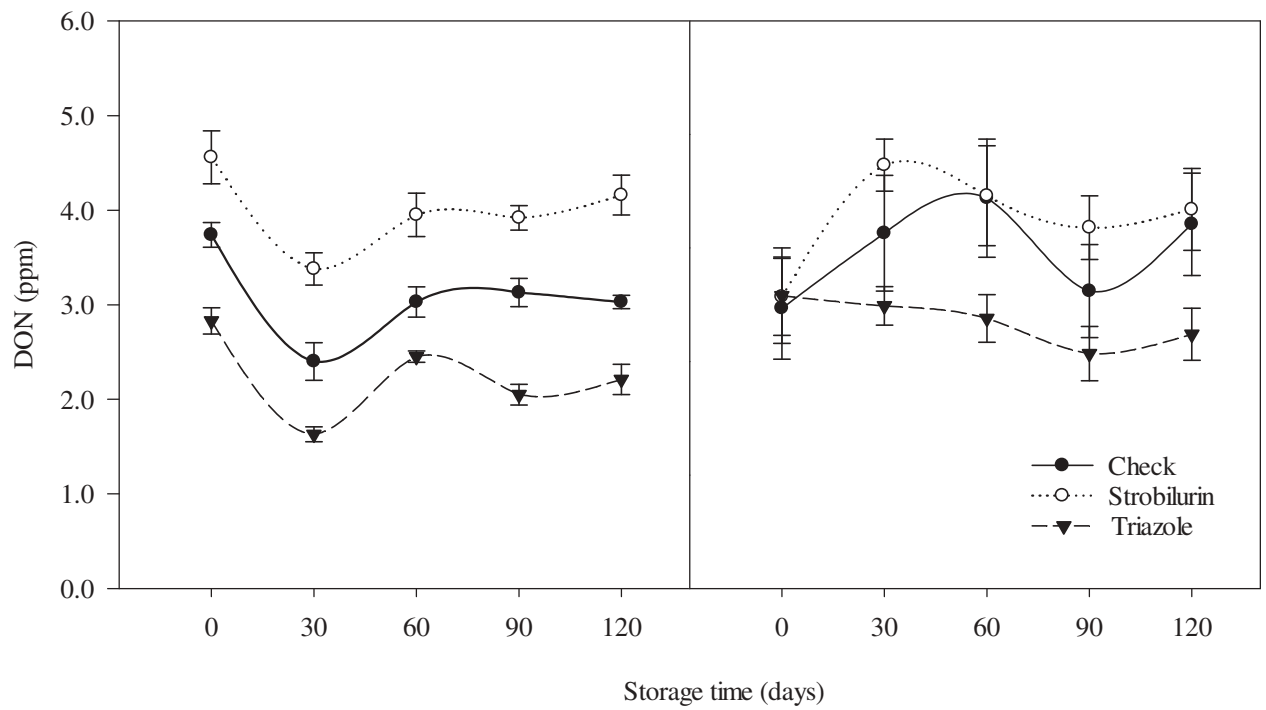

Fig. 3 DON concentration in grain of cv. 'Overland' (moderately resistant to FHB) (experiment 1), and cv. 'Overley' (susceptible to FHB) (experiment 2) for the combinations of fungicide treatments by postharvest storage time. LS-means are from two independent runs of each experiment. Error bars indicate SE of the LS-means.

et al. 2008; Kumar et al. 2015). Our results showed significantly higher $\left(\chi^{2} ; \mathrm{P}<0.001\right)$ frequency of Tri5 detection in the FHB-susceptible ('Overley') compared with the FHB-moderately resistant ('Overland') cultivar. Jansen et al. (2005) reported that the progress of infection in an FHB-moderately resistant barley (Hordeum vulgare) cultivar was slower than in FHB-susceptible cultivars. In addition, Hallen-Adams et al. (2011) found that spring wheat carrying the FHB1 QTL for FHB resistance showed minimal detection of Tri5 and significant deviation in Tri5 gene expression compared with an FHB-susceptible cultivar (lacking FHB1).

Results from this study suggest that $F$. graminearum is capable of activating Tri5 gene expression and promoting 


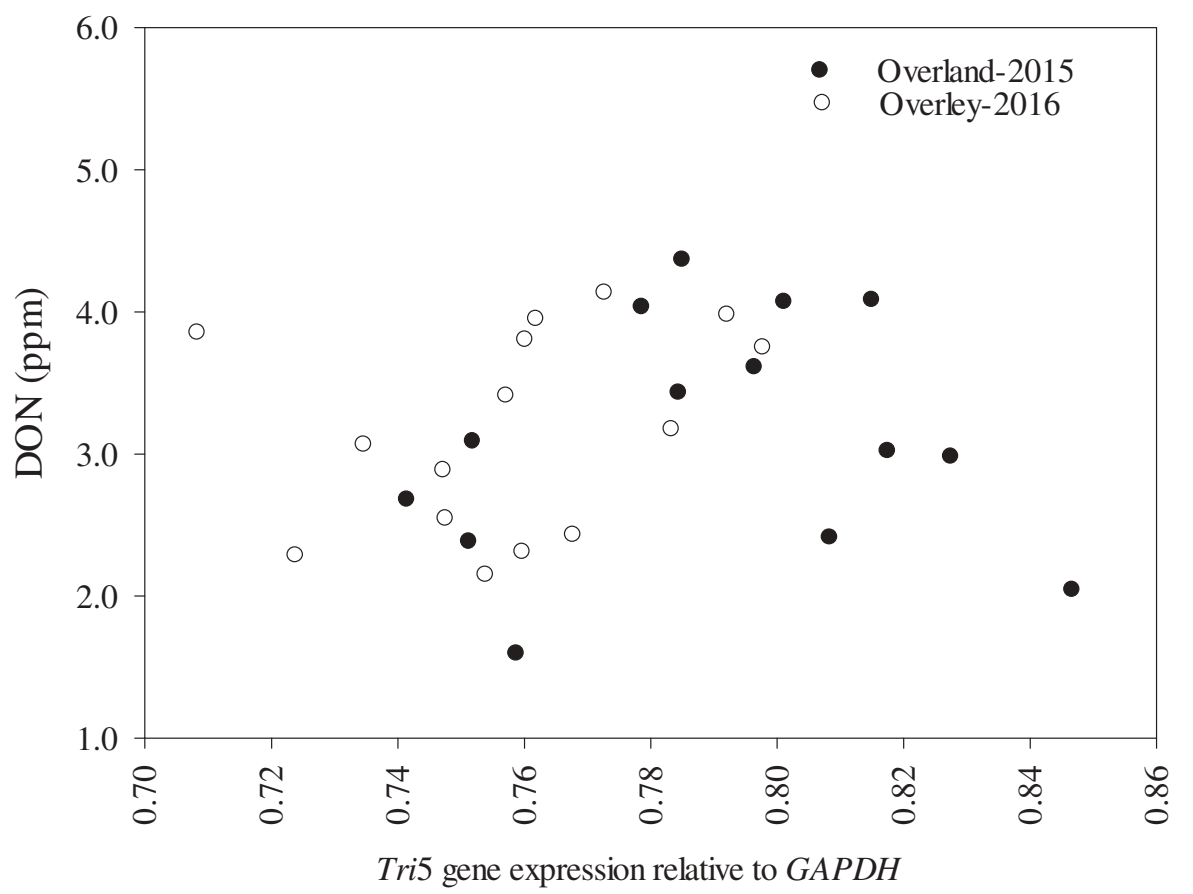

Fig. 4 Scatter plot showing the amount of DON and Tri5 gene expression relative to GAPDH in grain of cv. 'Overland' (moderately resistant to FHB) (experiment 1), and cv. 'Overley' (susceptible to FHB) (experiment 2) for the combinations of fungicide treatments by postharvest storage time $(n=15)$. LS-means are from two independent runs of each experiment.

disease in cv. 'Overley', and that this activation is diminished or delayed in cv. 'Overland'. Levels of expression of the Tri5 gene by F. graminearum may be related to the activation of genes of resistance or susceptibility by the host. Gene expression is highly variable between an FHBsusceptible and an FHB-moderately resistant cultivar. In a microarray study conducted by Bernardo et al. (2007), as many as $86 \%$ of the wheat genes differentially expressed in response to $F$. graminearum came from the FHB-susceptible cultivar ('Clark'), and $14 \%$ of the genes came from the FHB-moderately resistant cultivar (Ning 7840). Products of genes specific to the FHB-susceptible cultivar could trigger the expression of Tri5 in $F$. graminearum, and therefore increase Tri5 detection in the FHB-susceptible compared with the FHB-moderately resistant cultivar.

Fungicides applied to control FHB pathogens may reduce the amount of trichothecene-producing Fusarium present in grain and, indirectly, DON concentrations (Pirgozliev et al. 2002). In the FHB-susceptible cultivar ('Overley'), the Tri5 gene expression levels were lower in grain that came from triazole-treated plots than either non-fungicide treated check or strobilurin-treated plots. Furthermore, only in grain from triazole-treated plots was there a significant reduction in the relative expression of the Tri5 detected, while in the grain from the non-sprayed check plots and strobilurin-treated plots, an increase in the relative expression of the Tri5 was detected at the end of the postharvest experiments. Therefore, the population of $F$. graminearum actively producing DON was apparently diminished by triazole. Conversely, in grain from strobilurin-treated plots the expression of Tri5 increased after tempering the grain (30 days) in both experiments (Fig. 1). Tri5 gene expression decreased in wheat treated with triazole. In addition, Tri5 was significantly downregulated from 60 to 120 days of storage. However, DON was still being produced in stored grain 120 days after harvest. These findings emphasize the value of triazole fungicide usage (and the fact that treating wheat for foliar diseases with strobilurins will not protect against head blight).

Storage conditions, especially grain moisture, have a significant impact on DON. This study demonstrates that the expression of the Tri5 gene (necessary for the production of DON) can increase postharvest due to the presence of a transcriptionally active mass of fungi under conditions of high grain moisture content. In grain of both cultivars, the high and constant expression of the housekeeping gene GAPDH indicated the presence of living postharvest fungi (Table 2). There is potential for 
metabolically active fungi to grow and produce toxin during several months of storage. Transcriptional activity of the Tri5 gene from $F$. graminearum was detectable in grain with high grain moisture content $\left(20 \%, \mathrm{a}_{\mathrm{w}}=0.75\right)$ after 120 days of postharvest storage. Hallen-Adams et al. (2011) detected Tri5 activity in senescent tissue of a susceptible cultivar. The authors suggested the ability of the fungus to resume DON biosynthesis in dried infected grain. This study corroborates that suggestion, demonstrating increases of transcriptional activity of F. graminearum-Tri5 from 0 to 120 days after tempering the grain. In dried grain $(<14 \%$ moisture content), $F$. graminearum can physiologically adapt to the stress and escape dry conditions. Fusarium graminearum has an extraordinary survival ability, even growing after treatments of $-70^{\circ} \mathrm{C}$ for 2 hours and $65^{\circ} \mathrm{C}$ for one hour (Vujanovic et al. 2012).

Tri5 gene expression was not a good predictor of deoxynivalenol grain concentration, as DON was not correlated with Tri5 relative expression. Similarly, Bernáldez et al. (2017) found that the expression of the aft $\mathrm{R}$ aflatoxin regulatory gene in Aspergillus flavus was not a good indicator of aflatoxin B1 production. These results are in agreement with Hallen-Adams et al. (2011) who detected inconsistent results of Tri5 expression relative to fungal GAPDH and DON concentration. Regulation of the trichothecene production is complex, with unknown positive and negative factors affecting the expression of the toxin gene Tri5 (Hallen-Adams et al. 2011) and other genes in the Tri cluster (Jiao et al. 2008; Schmidt-Heydt et al. 2011). Early induction of Tri genes in asymptotic tissue has been detected in several studies (Mudge et al. 2006; Hallen-Adams et al. 2011; Brown et al. 2012; Chetouhi et al. 2016). Lee et al. (2014) hypothesized that a high level of Tri transcript accumulation is necessary before initiating DON biosynthesis. Tri gene expression has been shown to be maximal during symptomless infection. If DON biosynthesis is dependent on an initial Tri accumulation, then direct temporal correlations between DON and gene expression of members of the Tri cluster are unlikely.

In conclusion, DON can be present during postharvest storage even if $F$. graminearum is not actively transcribing Tri5. Cultivar resistance to FHB and field-applied fungicide chemical class seem to affect expression and, consequently, detection of the Tri5 gene. If conditions are favourable for mould growth, $F$. graminearum can express Tri5 and lead to a higher accumulation of DON in grain storage. Management strategies, in particular cultivar resistance (Šíp et al. 2010; Mesterhazy 2014) and field-applied fungicide chemical class (Blandino and Reyneri 2009; Wegulo 2012; Willyerd et al. 2012) can significantly impact the quality of grain during storage. The results from this study suggest the integration of cultivar resistance with triazole fungicides applied at anthesis to reduce postharvest $F$. graminearum growth and DON production in grain during storage.

\section{Acknowledgements}

The first author was supported by a scholarship awarded by The Secretariat of Higher Education, Science, Technology and Innovation of Ecuador. The authors are indebted to the Nebraska Wheat Board for partial funding of this research. This work was supported in part by grants to S.N. Wegulo (Agreement No. 59-0790-7-080) and D.G. Schmale III (VT PANs \#422288, \#422533) from the U.S. Wheat and Barley Scab Initiative. This work was supported in part by the Nebraska Agricultural Experiment Station with funding from the Hatch Multistate Research Capacity Funding Program (Accession Number 1006715). This material is based upon work supported by the U.S. Department of Agriculture. This is a cooperative project with the U.S. Wheat \& Barley Scab Initiative. Any opinions, findings, conclusions, or recommendations expressed in this publication are those of the authors and do not necessarily reflect the view of the U.S. Department of Agriculture.

\section{Funding}

This work was supported by the U.S. Department of Agriculture; The Secretariat of Higher Education, Science, Technology and Innovation of Ecuador; Nebraska Wheat Board; U.S. Wheat and Barley Scab Initiative [59-0790-7-080; \#422288; \#422533]; Hatch Multistate Research Capacity Funding Program [1006715].

\section{Supplemental material}

Supplemental data for this article can be accessed online here: https://doi.org/10.1080/07060661.2019.1700169.

\section{References}

Aldred D, Magan N. 2004. Prevention strategies for trichothecenes. Toxicol Lett. 153:165-171.

Amarasinghe CC, Tamburic-Ilincic L, Gilbert J, Brule-Babel AL, Fernando D. 2013. Evaluation of different fungicides for control of Fusarium head blight in wheat inoculated with $3 \mathrm{ADON}$ and 15ADON 
chemotypes of Fusarium graminearum in Canada. Can J Plant Pathol. 35:200-208.

Baenziger PS, Beecher B, Graybosch RA, Ibrahim A, Baltensperger DD, Nelson LA, Jin Y, Wegulo SN, Watkins JE, Hatchett JH. 2008. Registration of 'NE01643'wheat. J Plant Regist. 2:36-42.

Bai G, Desjardins AE, Plattner RD. 2001. Deoxynivalenolnonproducing Fusarium graminearum causes initial infection, but does not cause disease spread in wheat spikes. Mycopathologia. 153:91-98.

Bernáldez V, Córdoba JJ, Magan N, Peromingo B, Rodríguez A. 2017. The influence of ecophysiological factors on growth, aflR gene expression and aflatoxin B1 production by a type strain of Aspergillus flavus. Food Sci Technol. 83:283-291.

Bernardo A, Bai G, Guo P, Xiao K, Guenzi AC, Ayoubi P. 2007. Fusarium graminearum-induced changes in gene expression between Fusarium head blight-resistant and susceptible wheat cultivars. Funct Integr Genomics. 7:69-77.

Blandino M, Reyneri A. 2009. Effect of fungicide and foliar fertilizer application to winter wheat at anthesis on flag leaf senescence, grain yield, flour bread-making quality and DON contamination. Eur J Agron. 30:275-282.

Brown NA, Antoniw J, Hammond-Kosack KE. 2012. The predicted secretome of the plant pathogenic fungus Fusarium graminearum: A refined comparative analysis. PloS One. 7(4):e33731.

Chetouhi C, Bonhomme L, Lasserre-Zuber P, Cambon F, Pelletier S, Renou J, Langin T. 2016. Transcriptome dynamics of a susceptible wheat upon fusarium head blight reveals that molecular responses to Fusarium graminearum infection fit over the grain development processes. Funct Integr Genomics. 16:183-201.

Comerio RM, Pinto VF, Vaamonde G. 1999. Influence of water activity on deoxynivalenol accumulation in wheat. Mycotoxin Res. 15:24-32.

Demeke T, Gräfenhan T, Clear RM, Phan A, Ratnayaka I, Chapados J, Seifert KA. 2010. Development of a specific TaqMan ${ }^{\circledR}$ real-time PCR assay for quantification of Fusarium graminearum clade 7 and comparison of fungal biomass determined by PCR with deoxynivalenol content in wheat and barley. Int J Food Microbiol. 141:45-50.

Desjardins AE. 2006. Fusarium mycotoxins: chemistry, genetics and biology. St. Paul (MN): American Phytopathological Society.

Doohan FM, Parry DW, Nicholson P. 1999. Fusarium ear blight of wheat: the use of quantitative PCR and visual disease assessment in studies of disease control. Plant Pathol. 48:209-217.

Edwards SG, Pirgozliev SR, Hare MC, Jenkinson P. 2001. Quantification of trichothecene producing Fusarium species in harvested grain by competitive PCR to determine efficacies of fungicides against Fusarium head blight of winter wheat. Appl Environ Microbiol. 67:1575-1580.

Ellner FM. 2005. Results of long-term field studies into the effect of strobilurin containing fungicides on the production of mycotoxins in several winter wheat varieties. Mycotoxin Res. 21:112-115.

Fritz A, Martin TJ, Shroyer JP. 2004. Overley hard red wheat. Kansas State University, Agricultural Experiment Station and Cooperative Extension Service. [accessed 2018 Mar 01]. https://www.bookstore. ksre.ksu.edu/pubs/L924.pdf.

Glynn NC, Ray R, Edwards SG, Hare MC, Parry DW, Barnett CJ, Beck JJ. 2007. Quantitative Fusarium spp. and Microdochium spp. PCR assays to evaluate seed treatments for the control of Fusarium seedling blight of wheat. J Appl Microbiol. 102:1645-1653.

Gomez KA, Gomez AA. 1984. Statistical procedures for agricultural research. 2nd ed. New York (US): John Wiley \& Sons; 704 p.

Goswami RS, Xu J, Trail F, Hilburn K, Kistler HC. 2006. Genomic analysis of host-pathogen interaction between Fusarium graminearum and wheat during early stages of disease development. Microbiology. 152:1877-1890.
Hallen-Adams HE, Wenner N, Kuldau GA, Trail F. 2011. Deoxynivalenol biosynthesis-related gene expression during wheat kernel colonization by Fusarium graminearum. Phytopathology. 101:1091-1096.

Haubruge E, Chasseur C, Suetens C, Mathieu F, Begaux F, Malaisse F. 2003. Mycotoxins in stored barley (Hordeum vulgare) in Tibet autonomous region (People's Republic of China). Mt Res Dev. 23:284-287.

Hohn TM, Beremand PD. 1989. Isolation and nucleotide sequence of a sesquiterpene cyclase gene from the trichothecene-producing fungus Fusarium sporotrichioides. Gene. 79:131-138.

Hope R, Aldred D, Magan N. 2005. Comparison of environmental profiles for growth and deoxynivalenol production by Fusarium culmorum and F. graminearum on wheat grain. Lett Appl Microbiol. 40:295-300.

Horevaj P, Milus EA, Bluhm BH. 2011. A real-time qPCR assay to quantify Fusarium graminearum biomass in wheat kernels. J Appl Microbiol. 111:396-406.

Jansen C, von Wettstein D, Schäfer W, Kogel K-H, Felk A, Maier FJ. 2005. Infection patterns in barley and wheat spikes inoculated with wild-type and trichodiene synthase gene disrupted Fusarium graminearum. Proc Natl Acad Sci USA. 102:16892-16897.

Jiao F, Kawakami A, Nakajima T. 2008. Effects of different carbon sources on trichothecene production and Tri gene expression by Fusarium graminearum in liquid culture. FEMS Microbiol Lett. 285:212-219.

Jin F, Zhang D, Bockus W, Baenziger PS, Carver B, Bai G. 2013. Fusarium head blight resistance in US winter wheat cultivars and elite breeding lines. Crop Sci. 53:2006-2013.

Kumar A, Karre S, Dhokane D, Kage U, Hukkeri S, Kushalappa AC. 2015. Real-time quantitative PCR based method for the quantification of fungal biomass to discriminate quantitative resistance in barley and wheat genotypes to fusarium head blight. J Cereal Sci. 64:16-22.

Lee T, Lee S, Shin JY, Kim H, Yun S, Kim H, Lee S, Ryu J. 2014. Comparison of trichothecene biosynthetic gene expression between Fusarium graminearum and Fusarium asiaticum. Plant Pathol J. 30:33-42.

Li X, Shin S, Heinen S, Dill-Macky R, Berthiller F, Nersesian N, Clemente T, McCormick S, Muehlbauer GJ. 2015. Transgenic wheat expressing a barley UDP-glucosyltransferase detoxifies deoxynivalenol and provides high levels of resistance to Fusarium graminearum. Mol Plant Microbe Interact. 28:1237-1246.

Madden LV, Bradley C, DaSilva F, Paul PA. 2014. Meta-analysis of 19 years of fungicide trials for the control of Fusarium head blight of wheat. Proceedings 2014 National Fusarium Head Blight Forum; Bloomington, MN. East Lansing: Hyatt Regency St. Louis at the Arch St. Louis; p. 129-132.

Magan N, Aldred D, Baxter ES. 2014. Good postharvest storage practices for wheat grain. In: Leslie JF, Logrieco AF, editors. Mycotoxin reduction in grain chains. Chichester (UK): John Wiley \& Sons Ltd.; p. 258-267.

Marin P, Magan N, Vazquez C, Gonzalez MT. 2010. Differential effect of environmental conditions on the growth and regulation of the fumonisin biosynthetic gene FUM1 in the maize pathogens and fumonisin producers Fusarium verticillioides and Fusarium proliferatum. FEMS Microbiol Ecol. 73:303-311.

Mesterhazy A. 2014. 13 breeding for resistance to fusarium head blight in wheat. In: Leslie JF, Logrieco AF, editors. Mycotoxin reduction in grain chains. Chichester (UK): John Wiley \& Sons Ltd.; p. 189-208.

Mesterhazy A, Bartok T, Lamper C. 2003. Influence of wheat cultivar, species of Fusarium, and isolate aggressiveness on the efficacy of fungicides for control of Fusarium head blight. Plant Dis. 87:1107-1115. 
Mudge AM, Dill-Macky R, Dong Y, Gardiner DM, White RG, Manners JM. 2006. A role for the mycotoxin deoxynivalenol in stem colonization during crown rot disease of wheat caused by Fusarium graminearum and Fusarium pseudograminearum. Physiol Mol Plant Pathol. 69:73-85.

Pirgozliev SR, Edwards SG, Hare MC, Jenkinson P. 2002. Effect of dose rate of azoxystrobin and metconazole on the development of Fusarium head blight and the accumulation of deoxynivalenol (DON) in wheat grain. Eur J Plant Pathol. 108:469-478.

Proctor RH, Hohn TM, McCormick SP. 1995. Reduced virulence of Gibberella zeae caused by disruption of a trichothecene toxin biosynthetic gene. Mol Plant Microbe Interact. 8:593-601.

Schmidt-Heydt M, Parra R, Geisen R, Magan N. 2011. Modelling the relationship between environmental factors, transcriptional genes and deoxynivalenol mycotoxin production by strains of two Fusarium species. J R Soc Interface. 8:117-126.

Schmittgen TD, Livak KJ. 2008. Analyzing real-time PCR data by the comparative C T method. Nat Prot. 3:1101-1108.

Šíp V, Chrpová J, Veškrna O, Bobková L. 2010. The impact of cultivar resistance and fungicide treatment on mycotoxin content in grain and yield losses caused by Fusarium head blight in wheat. Czech J Genet Plant Breeding. 46:21-26.
Simpson DR, Weston GE, Turner JA, Jennings P, Nicholson P. 2001. Differential control of head blight pathogens of wheat by fungicides and consequences for mycotoxin contamination of grain. Eur J Plant Pathol. 107:421-431.

Vujanovic V, Goh YK, Daida P. 2012. Heat-and cold-shock responses in Fusarium graminearum 3 acetyl-and 15 acetyl-deoxynivalenol chemotypes. J Microbiol. 50:97-102.

Wegulo SN. 2012. Factors influencing deoxynivalenol accumulation in small grain cereals. Toxins. 4:1157-1180.

Wegulo SN, Baenziger PS, Hernandez Nopsa J, Bockus WW, Hallen-Adams H. 2015. Management of Fusarium head blight of wheat and barley. Crop Prot. 73:100-107.

Wegulo SN, Bockus WW, Hernandez Nopsa J, De Wolf ED, Eskridge KM, Peiris KHS, Dowell FE. 2011. Effects of integrating cultivar resistance and fungicide application on Fusarium head blight and deoxynivalenol in winter wheat. Plant Dis. 95:554560 .

Willyerd KT, Li C, Madden LV, Bradley CA, Bergstrom GC, Sweets LE, McMullen M, Ransom JK, Grybauskas A, Osborne L. 2012. Efficacy and stability of integrating fungicide and cultivar resistance to manage Fusarium head blight and deoxynivalenol in wheat. Plant Dis. 96:957-967. 